\title{
PEMBENTUKAN KARAKTER PESERTA DIDIK MELALUI SOSIODRAMA
}

\author{
Fiyan Ilman Faqih \\ Universitas Trunojoyo Madura, Jalan Raya Telang, Bangkalan \\ E-mail: fiyan.faqih@trunojoyo.ac.id
}

\begin{abstract}
Abstrak
Karakter peserta didik saat ini sangat memprihatinkan. Banyak tindak kriminal yang dilakukan oleh peserta didik. Maka dari itu, artikel ini bertujuan mendeskripsikan pembentukan karakter peserta didik dapat dilakukan dengan menggunakan metode pembelajaran sosiodrama. Adapun karakter peserta didik yang dibentuk, yaitu pengetahuan moral (moral knowing), perasaan moral (moral feeling), dan perilaku moral (moral action). Alasan penggunaan sosiodrama dalam pembentukan karakter peserta didik karena metode ini dapat menciptakan proses pembelajaran lebih menarik dan tidak membosankan.
\end{abstract}

Kata kunci: karakter peserta didik, sosiodrama

\section{Pendahuluan}

Karakter peserta didik, baik itu di SD, SMP, atau SMA semakin terpendam dalam jurang keterpurukan moral. Hal itu tergambar jelas pada banyaknya berita-berita tindak kriminal yang dilakukan oleh peserta didik. Indonesia Police Watch (IPW) dalam salah satu media online, yakni okezone.com (2014) menerangkan bahwa terdapat 12 peserta didik yang terlibat kejahatan sadis, seperti pembunuhan dan perampokan. Ironisnya sebagian besar korbannya ialah teman pelaku. Contohnya, 3 peserta didik yang masing-masing berusia 14,15 , dan 16 tahun membunuh temannya karena hanya korban mengolok-olok pelaku. Tidak hanya itu, contoh lainnya ialah peserta didik yang berusia 12 tahun terlibat perampokan dan peserta didik yang berusia 10 tahun menganiaya temannya hingga tewas. Tindak kriminal tidak hanya dilakukan oleh peserta didik yang berusia 10 tahun atau di atas 10 tahun, tetapi tindak kriminal juga dilakukan oleh peserta didik yang berusia di bawah 10 tahun. Contohnya, republika.co.id (2015) memberitakan bahwa peserta didik yang masih kelas $2 \mathrm{SD}$ tewas dianiaya oleh kedua temannya. Selain itu, wavienews.com juga memberitakan bahwa dua peserta didik yang masih duduk di bangku SD memperkosa seorang siswi. Berita yang terbaru terjadi di tahun 2019 ialah salah satu siswa SMP berani menantang guru dengan sangat tidak hormat.

Keterpurukan moral peserta didik merupakan tamparan bagi dunia pendidikan di Indonesia. Muslich (2011:3) menegaskan bahwa banyak faktor yang menyebakan runtuhnya potensi bangsa Indonesia, di antaranya ialah runtuhnya faktor pendidikan. Pendidikan merupakan tiang pancang untuk mengenalkan, membentuk, dan mengembangkan karakter peserta didik. Jika tiang tersebut rubuh, maka rubuhlah karakter peserta didik. Peserta didik tidak cukup mengetahui uraian materi nilai-nilai karakter, tetapi peserta didik juga dituntut untuk mengaplikasikan nilai-nilai karakter tersebut. Maka dari itu, pendidik tidak hanya dituntut mampu mengajar peserta didik, tetapi peserta didik juga dituntut mampu mendidik peserta didik.

Salah satu metode yang dapat digunakan pendidik dalam mendidik peserta didik, yaitu metode pembelajaran sosiodrama. Penggunaan metode ini bertujuan untuk membentuk karakter peserta didik sehingga semua tindakan peserta didik terkontrol (berdasarkan nilai-nilai karakter). Selain itu, penggunaan metode ini juga bertujuan untuk meningkatkan hasil belajar peserta didik. Metode ini digunakan karena metode ini dapat menciptakan pembelajaran yang menarik dan tidak membosankan.

\section{Pembahasan \\ Pembentukan Karakter}

Ryan dan Bohlin (dalam Suyadi, 2013:5) menjelaskan bahwa secara epistemilogis, kata "karakter" atau character dalam bahasa Inggris berasal dari bahasa Yunani, yaitu eharassein yang berarti to engrave. Kata to engrave itu dapat diterjemahkan menjadi mengukir, melukis, mamahat, atau menggores. Sementara itu, pada bahasa Indonesia, kata "karakter" diartikan sebagai tabiat, sifat kejiwaan, akhlak, atau budi pekerti yang membedakan seseorang dengan 


\section{Volume 4 No. 1 METALINGUA \\ April 2019 Jurnal Pendidikan Bahasa dan Sastra Indonesia}

orang lain. Suyadi (2013:5) menjelaskan bahwa karakter merupakan nilai-nilai universal dari perilaku manusia yang meliputi seluruh aktivitas kehidupan, baik yang berhubungan dengan Tuhan, diri sendiri, sesama manusia, maupun dengan lingkungan. Sementara itu, Kesuma, Triatna, dan Permana (2013:6) menjelaskan bahwa karakter merupakan ciri khas seseorang. Maka dari itu, berdasarkan asal mula kata "karakter" dan penjelasan dari beberapa ahli, dapat disimpulkan bahwa karakter ialah kepribadian seseorang (peserta didik) untuk melakukan tindakan yang benar dalam seluruh aktivitas kehidupannya, baik yang berhubungan dengan Tuhan, diri sendiri, sesama manusia, maupun dengan lingkungan.

Lickona (2012:82) membagi karakter menjadi tiga aspek, yaitu pengetahuan moral (mengetahui hal yang baik), perasaan moral (menginginkan hal yang baik), dan perilaku moral (melakukan hal yang baik). Pertama, pengetahuan moral. Pengetahuan moral terdiri atas enam aspek, yaitu (a) kesadaran moral: memahami informasi dari permasalahan yang bersangkutan, (b) pengetahuan nilai moral: mengetahui bagaimana cara menerapkan nilai, (c) penentuan perspektif: kemampuan mengambil sudut pandang orang lain, (d) pemikiran moral: pemahaman tentang apa yang dimaksud moral dan mengapa aspek moral tersebut, (e) pengambilan keputusan: mampu memikirkan acara seseorang bertindak melalui permasalahan moral, dan (f) pengetahuan pribadi: kemampuan untuk mengevaluasi diri sendiri. Kedua, perasaan moral. Muslish (2011:134) mengatakan bahwa perasaan moral, yaitu aspek yang harus ditanamkan kepada anak karena merupakan tindakan yang sesuai dengan prinsip moral. Contohnya, seberapa jauh siswa peduli tentang bersikap jujur dan adil kepada orang lain. Hanya mengetahui apa yang benar bukan merupakan jaminan untuk melakukan tindakan yang baik. Siswa bisa jadi sangat pintar tentang perihal benar dan salah tetapi siswa masih memilih yang salah daripada yang benar. Perasaan moral terdiri atas enam aspek, yaitu (a) hati nurani: mengetahui apa yang benar dan kewajiban apa yang harus dilakukan, (b) harga diri: penghargaan untuk diri sendiri, (c) empati: pengalaman seolah-olah menjadi orang lain, (d) mencintai hal yang baik: rasa tertarik kepada hal yang baik, (e) kendali diri: menahan diri sendiri, dan (f) kerendahan hati: tidak sombong. Ketiga, perilaku moral. Muslich (2011:134) menjelaskan bahwa perilaku moral berkaitan dengan bagaimana membuat pengetahuan moral dapat diwujudkan menjadi tindakan nyata. Tindakan moral merupakan hasil dari pengetahuan dan perasaan moral. Perilaku moral terdiri atas tiga aspek, yaitu (a) kompetensi: kemampuan untuk mengubah penilaian dan perasaan moral ke dalam tindakan moral yang efektif, (b) keinginan: hal yang melandasi perbuatan baik, dan (c) kebiasaan: pengalaman yang diulang-ulang.

Ada 18 nilai karakter dalam pendidikan Indonesia yang harus diketahui, dirasakan, dan dilaksanakan oleh setiap peserta didik. Samani \& Hariyanto (2013:52) menjelaskan bahwa nilai karakter Indonesia bersumber dari agama, pancasila, budaya, dan tujuan pendidikan nasional. Adapun 18 nilai karakter tersebut, yaitu:

1) Religius: ketaatan dan kepatuhan dalam memahami dan melaksanakan ajaran agama yang dianut, termasuk dalam hal ini ialah sikap toleran terhadap pelaksanaan ibadah agama lain, serta hidup rukun dan berdampingan.

2) Jujur: sikap dan perilaku yang mencerminkan kesatuan antara pengetahuan, perkataan, dan perbuatan, sehingga menjadikan orang yang bersangkutan sebagai pribadi yang dapat dipercaya.

3) Toleransi: sikap dan perilaku yang mencerminkan penghargaan terhadap perbedaan agama, aliran kepercayaan, suku, adat, bahasa, ras, etnis, pendapat, dan hal-hal yang berbeda dengan dirinya sendiri secara sadar dan terbuka, serta dapat hidup tenang di tengah perbedaan tersebut.

4) Disiplin: kebiasaan dan tindakan yang konsisten terhadap segala bentuk peraturan atau tata tertib yang belaku.

5) Kerja keras: perilaku yang menunjukkan upaya secara sungguh-sungguh dalam menyelesaikan berbagai tugas, permasalahan, pekerjaan, dan lain-lain dengan sebaik-baiknya.

6) Kreatif: sikap dan perilaku yang mencerminkan inovasi dalam berbagai segi dalam memecahkan masalah, sehingga selalu menemukan cara-cara baru, bahkan hasil-hasil baru yang lebih baik dari sebelumnya.

7) Mandiri: sikap dan perilaku yang tidak bergantung pada orang lain dalam menyelesaikan berbagai tugas maupun persolan. Namun, hal ini bukan berarti tidak 
boleh bekerjasama secara kolaboratif, melainkan tidak boleh melemparkan tugas dan tanggung jawab kepada orang lain.

8) Demokratis: sikap dan cara berpikir yang mencerminkan persamaan hak dan kewajiban secara adil dan merasa antara dirinya dengan orang lain.

9) Rasa ingin tahu: cara berpikir, sikap, dan perilaku yang mencerminkan rasa keingintahuan terhadap segala hal yang dilihat, didengar, dan dipelajari secara lebih mendalam.

10) Semangat kebangsaan atau nasionalisme: sikap dan tindakan yang menempatkan kepentingan bangsa dan negara di atas kepentingan kepentingan pribadi atau individu dan golongan.

11) Cinta tanah air: sikap dan perilaku yang mencerminkan rasa bangga, setia, peduli, dan penghargaan yang tinggi terhadap bahasa, budaya, ekonomi, politik, dan sebagainya, sehingga tidak mudah menerima tawaran bangsa lain yang dapat merugikan bangsa sendiri.

12) Menghargai prestasi: sikap terbuka terhadap prestasi orang lain dan mengakui kekurangan diri sendiri tanpa mengurangi semangat berprestasi yang lebih tinggi.

13) Komunikatif, senang bersahabat atau proaktif: sikap dan tindakan terbuka terhadap orang lain melalui komunikasi yang santun sehingga tercipta kerja sama kolaboratif dengan baik..

14) Cinta damai: sikap dan perilaku yang mencerminkan suasana damai, aman, tenang, dan nyaman atas kehadiran dirinya dalam komunitas atau masyarakat tertentu.

15) Gemar membaca: kebiasaan dengan tanpa paksaan untuk menyediakan waktu secara khusus guna membaca berbagai informasi, baik buku, jurnal, majalah, koran, dan sebagainya, sehingga menimbulkan kebijakan bagi dirinya.

16) Peduli lingkungan: sikap dan tindakan yang selalu berupaya menjaga dan melestarikan lengkungan sekitar.

17) Peduli sosial: sikap dan perbuatan yang mencerminkan kepedulian terhadap orang lain maupun masyarakat yang membutuhkannya.

18) Tanggung jawab: sikap dan perilaku seseorang dalam melaksanakan tugas dan kewajibannya, baik yang berkaitan dengan diri sendiri, sosial, masyarakat, bangsa, negara, maupun agama.

Dari 18 nilai karakter tersebut, ada tiga nilai karakter yang harus lebih diperkuat. Pusat Pengkajian Pedagogik Universitas Pendidikan Indonesia (P3 UPI) (dalam Kesuma, Triatna, dan Permana, 2012:16 - 21) bahwa ada tiga nilai yang harus diperkuat untuk pembangunan bangsa, yaitu jujur, kerja keras, dan ikhlas. Pertama, jujur merupakan keputusan seseorang untuk mengungkapkan (perasaan, kata-kata, dan perbuatan) dengan cara tidak memanipulasi atau berbohong. Adapun karakteristik sikap jujur, yaitu tekad dalam melakukan sesuatu berlandaskan kebenaran dan kemaslahatan, berkata tidak bohong (benar adanya), dan adanya kesamaan antara yang dikatakan hatinya dengan apa yang dilakukannya. Kedua, kerja keras merupakan suatu upaya yang terus dilakukan (tidak menyerah) dalam menyelesaikan pekerjaan yang telah menjadi tugasnya. Adapun karakteristik kerja keras, yaitu merasa risau jika pekerjaannya belum terselesaikan sampai tuntas, memeriksa hal yang harus dilakukan yang telah menjadi tanggung jawabnya dalam suatu jabatan/posisi, mampu mengatur waktu yang dimilikinya, dan mampu mengorganisasikan sumber daya yang ada untuk menyelesaikan tugas dan tanggung jawabnya. Ketiga, ikhlas merupakan upaya yang teguh dalam melaksanakan hal yang benar dengan motif yang transparan, tanpa mengharapkan adanya pujian atau balasan dari orang lain (Samani dan Hariyanto, 2013:131). Orientasi pekerjaan yang dilakukan bukan untuk mendapatkan penghargaan dari teman atau lingkungan, tetapi untuk mendapatkan keridhaan Tuhan. Ada tiga karakteristik perilaku ikhlas, yaitu konsistensi yang kuat dari waktu ke waktu dari satu kondisi ke kondisi lainnya, harapan bagi pelaku ialah keridhaan dari Tuhan (bukan dari siapapun), dan memiliki karakteristik mutu yang lebih baik dari waktu ke waktu.

Sebenarnya, sasaran pembentukan karakter tidak hanya peserta didik, tetapi seluruh warga civitas akademika yang terdapat dalam setiap satuan pendidikan yang meliputi peserta didik, guru, karyawan, administrasi, dan pimpinan sekolah. Seperti yang dijelaskan oleh Lickona, Schaps, dan Lewis (2007:1) menjelaskan bahwa semua anggota sekolah bertanggung jawab atas standar perilaku yang sesuai dengan nilai-nilai etika. Namun, pada artikel ini pembentukan karakter dikhususkan 
untuk peserta didik karena karakter peserta didik pada saat ini jauh dari kata baik.

\section{Metode Pembelajaran Sosiodrama}

Sosiodrama bukan salah satu jenis drama dalam konteks dramaturgi. Kedudukan sosiodrama berbeda dengan kedudukan drama komedi, tragedi, tragedi komedi, melodrama, atau jenis drama lainnya. Hendriono (2011) menjelaskan bahwa sosiodrama adalah cara menyajikan bahan pelajaran dengan mempertontonkan tingkah laku dalam hubungan sosial. Saryono (2015) menegaskan bahwa sosiodrama merupakan wahana, wadah, atau sarana untuk menyampaikan informasi. Maka dari itu, sosiodrama merupakan salah satu metode pembelajaran untuk menyampaikan informasi (pelajaran) dengan cara membuat sebuah pertunjukan drama.

Pada umumnya, sosiodrama digunakan agar pembelajaran tidak membosankan. Sosiodrama dapat meningkatkan daya tarik penyampaian informasi (pelajaran). Ada empat tujuan yang diharapkan dengan penggunaan metode sosiodrama, yaitu (a) agar siswa dapat menghayati dan menghargai perasaan orang lain, (b) dapat belajar bagaimana menjalankan tanggung jawab, (c) dapat belajar bagaimana mengambil keputusan dalam situasi mendesak dan secara spontan, dan (d) merangsang kelas untuk berpikir dan memecahkan masalah. Maka dari itu, fokus dalam penggunaan metode pembelajaran sosiodrama bukanlah pada kemampuan peserta didik dalam bermain peran, tetapi pada informasi (pelajaran) yang disampaikan. Sosiodrama digunakan bukan untuk menjadikan peserta didik mahir dalam bermain peran, tetapi menjadikan peserta didik merasa senang dalam menerima pelajaran. Namun, kemampuan bermain peran dalam metode pembelajaran sosiodrama harus tetap diperhatikan karena tanpa kemampuan bermain peran tersebut informasi yang disampaikan sulit untuk diterima oleh peserta didik lainnya.

Saryono (2015) menjelaskan bahwa secara garis besar ada enam langkah dalam penggunaan metode pembelajaran sosiodrama. Pertama, penetapan tujuan pembelajaran, yakni apa maksud dan tujuan menggunakan metode pembelajaran sosiodrama. Kedua, pengidentifikasian dan penetapan tema, isi, dan bahan dalam sosiodrama, yakni perilaku etis dan moral apakah yang dijadikan tema, isi, dan bahan sosiodrama bagi anak-anak dan apakah tema, isi, dan bahan sosiodrama itu sudah sesuai dengan perkembangan intelektual dan moral anak-anak. Ketiga, pengidentifikasian, penetapan, dan pengembangan cerita sosiodrama, yakni bagaimanakah tema, isi, dan bahan sosiodrama dituangkan, diwadahi, dan dikembangkan ke dalam cerita. Keempat, pengidentifikasian, pemilihan, dan penetapan pemain-pemain sosiodrama, yakni berapakah pemain yang dibutuhkan untuk memainkan naskah atau skenario sosiodrama. Kelima, penggarapan dan latihan permainan sosiodrama, yakni berapa lama penggarapan dan latihan diperlukan. Keenam, pertunjukan dan pementasan sosiodrama, yakni bagaimana pertunjukan dan pementasan dirancang. Sementara itu, ada tujuh prinsip penggunaan metode pembelajaran sosiodrama, yaitu (a) dilakukan oleh sekelompok siswa, tiap kelompok mendapatkan kesempatan untuk melaksanakan cerita yang sama atau juga bisa berbeda, (b) semua siswa harus terlibat langsung sesuai peran masing-masing, (c) penentuan topik disesuaikan dengan tingkat kemampuan kelas, (d) petunjuk diberikan terlebih dahulu, (e) dalam sosiodrama seyogyanya dapat dicapai tiga nilai karakter, (f) dalam sosiodrama hendaknya digambarkan situasi yang lengkap, dan (g) hendaknya diusahakan terintegrasinya beberapa ilmu.

Ada lima kelebihan metode pembelajaran sosiodrama digunakan dalam pembelajaran. Pertama, dapat berkesan dengan kuat dan tahan lama dalam ingatan siswa. Di samping merupakan pengamanan yang menyenangkan yang saling untuk dilupakan. Kedua, sangat menarik bagi siswa, sehingga memungkinkan kelas menjadi dinamis dan penuh antusias. Ketiga, membangkitkan gairah dan semangat optimisme dalam diri siswa serta menumbuhkan rasa kebersamaan dan kesetiakawanan sosial yang tinggi. Keempat, dapat menghayati peristiwa yang berlangsung dengan mudah, dan dapat memetik butir-butir hikmah yang terkandung di dalamnya dengan penghayatan siswa sendiri. Kelima, dimungkinkan dapat meningkatkan kemampuan profesional siswa, dan dapat menumbuhkan/membuka kesempatan bagi lapangan kerja.

\section{Peran Sosiodrama dalam Membentuk Karakter Peserta Didik}

Pembentukan karakter tidak selalu dalam bentuk formal yang menjadi pelajaran tersendiri. Pembentukan karakter anak-anak bisa dilakukan 
dengan metode yang menarik. Lickona, Schaps, Lewis (2007:1) menjelaskan bahwa membangun karakter bisa melalui kurikulum tersembunyi, antara lain proses pembelajaran. Lickona, Schaps, Lewis (2007:2) juga mengatakan bahwa untuk mengembangkan karakter yang baik peserta didik perlu diberi kesempatan untuk menerapkan nilai-nilai karakter, karena pembelajaran yang baik adalah pembelajaran dengan cara melakukan. Rainer dan Lewis (2005:4) menjelaskan bahwa drama menekankan tujuan yang lebih penting terkait dengan pengembangan pribadi dan sosial. Maka dari itu, penerapan sosiodrama drama dalam proses pembelajaran merupakan cara yang efektif untuk membentuk karakter peserta didik.

Melalui metode pembelajaran sosiodrama, peserta didik dapat mengetahui, merasakan, dan melakukan nilai-nilai karakter. Sanjaya (2007:159) menjelaskan bahwa sosiodrama digunakan untuk memberikan pemahaman dan penghayatan akan masalah-masalah sosial serta mengembangkan kemampuan siswa untuk memecahkanya. Pada metode pembelajaran sosiodrama terdapat dialog-dialog dan tingkah laku yang berisi contoh, nasihat, dan hukuman yang berkaitan dengan pembentukan karakter. Pemanfaatan metode pembelajaran sosiodrama sebagai sarana pembentukan karakter juga dapat membatasi pengaruh budaya asing terhadap karakter bangsa. Namun, proses pembentukan karakter peserta didik tidak semudah dan secepat membalikkan telapak tangan. Pembentukan karakter peserta didik merupakan proses yang dilakukan secara bertahap dan berulang-ulang. Hal itu dilakukan karena peserta didik bukanlah benda, tetapi peserta didik merupakan manusia yang memiliki pikiran dan perasaan.

Metode pembelajaran sosiodrama mempunyai dua peran dalam pembentukan karakter peserta didik. Pertama, penerapan sosiodrama sebagai metode pembelajaran dapat membantu peserta didik dalam mengembangkan nilai-nilai yang ada dalam diri subjek peserta didik, memperkenalkan tentang kehidupan manusia (kebahagiaan, keberhasilan, kepuasan, kegembiraan, cinta, ketakutan, keputusasaan, acuh tak acuh, dan kehancuran) dan memberi sumbangan pada pengembangan kepribadian yang kompleks (ketegaran hati, akal yang panjang, imajinasi, dan kreativitas). Kedua, penerapan sosiodrama juga akan memperkaya nilai-nilai rekreatif. Di dalam metode pembelajaran sosiodrama terdapat nilai-nilai yang segar, dinamis, mengandung semangat, nilai moral, dan nilai estetis. Keberhasilan metode pembelajaran sosiodrama dalam membentuk karakter peserta didik akan menciptakan manusia-manusia yang lebih berbudaya.

Tidak semua nilai karakter dapat dicapai dalam pembelajaran yang menggunakan metode sosiodrama, hanya ada beberapa nilai karakter yang dapat dicapai. Hal itu berdasarkan nilai karakter apa yang akan diajarkan. Pemilihan nilai karakter tersebut juga akan mempengaruhi langkah-langkah pembelajaran yang akan dilakukan.

Metode pembelajaran sosiodrama juga dapat meningkatkan hasil belajar peserta didik. Alasannya karena karakter peserta didik berkaitan erat dengan keberhasilan peserta didik dalam belajar. Lickona, Schaps, dan Lewis (2007:1) menjelaskan bahwa pengembangan karakter berusaha untuk mengembangkan aspek kognitif, emosional, dan perilaku kehidupan moral. Maka dari itu, pembentukan karakter berpengaruh pada keberhasilan belajar. Pernyataan tersebut diperkuat dengan penjelasan Azzet (2014:41-50) yang menjelaskan bahwa ada beberapa faktor penyebab kegagalan anak di sekolah. Faktor-faktor tersebut bukan terletak pada kecerdasan intelektual, melainkan pada karakter siswa tersebut. adapun karakter tersebut, yaitu rasa percaya diri, kemampuan bekerjasama, kemampuan bergaul, kemampuan berempati, dan kemampuan berkomunikasi.

\section{Simpulan}

Penggunaan metode pembelajaran sosiodrama dalam pembelajaran di sekolah secara tidak langsung akan membentuk karakter peserta didik menjadi peserta didik yang mempunyai karakter yang menjunjung nilai-nilai moral yang baik dan benar. Penerapan metode pembelajaran sosiodrama juga akan mempermudah peserta didik mengingat materi pembelajaran, mengandung nilai hiburan sehingga tidak membosankan, dan membuat siswa peka terhadap lingkungannya. Penerapan metode pembelajaran sosiodrama juga dapat meningkatkan keberhasilan peserta didik dalam belajar. Hal itu terjadi karena peningkatan keberhasilan peserta didik dalam belajar dipengaruhi karakter peserta didik. 


\section{Daftar Rujukan}

Azzet, A. M. 2014. Urgensi pendidikan Karakter Di Indonesia. Yogyakarta: Ar-Ruzz Media.

Hendriono. 2011. Metode Pembelajaran Sosiodrama. (Online), $\quad 1-2$ http://skp.unair.ac.id/repository/GuruIndo nesia/MetodePembelajaran_Hendriono_1 1769.pdf, diakses 30 Maret 2014.

Iman, R. N. 20 April 2015. Dianiaya Temannya, Siswa Kelas 2 SD di Sukabumi Tewas. Republika.co.id.

Kesuma, D. Triatna, C., \& Permana, J. 2012. Pendidikan Karakter Kajian Teori dan Praktik di Sekolah. Bandung: Remaja Rosdakarya.

Muslich, M. 2011. Pendidikan karakter menjawab tantangan kritis multidimensional. Jakarta: Bumi Aksara.

Lickona, T. Mendidik untuk Membentuk Karakter. Terjemahan Juma Abdu Wamaungo. 2012. Jakarta: Bumi Aksara.

Lickona, T, Schaps, E, \& Lewis, C. 2007. Eleven Principles of Effective Character Education. Washington DC: CEP.

Rainer, J \& Lewis, M. 2005. Teaching Drama and Theatre in The Secondary School. London: Rputledge.

Samani, M. \& Hariyanto. 2013. Pendidikan Karakter. Bandung: Remaja Roasdakarya.

Sanjaya, W. 2007. Strategi Pembelajaran Berorientasi Standar Proses Pendidikan. Jakarta: Kencana Prenada Media Group.

Saryono, D. 2015. Pembelajaran Sosiodrama. Makalah tidak diterbitkan. Malang: PPs UM.

Suryana, D. 9 Oktober 2014. Ironi, 12 Anak Sekolah Terlibat Kejahatan Sadis. Okezone.com.

Suyadi. 2013. Strategi Pembelajaran Pendidikan Karakter (Engkus Kuswandi). Bandung: Remaja Rosdakarya. 